\title{
Long non-coding RNA H19 deficiency ameliorates bleomycin-induced pulmonary inflammation and fibrosis
}

\author{
Xiaoyu Wan ${ }^{1}$, Xinbei Tian ${ }^{2}$, Jun Du², Ying Lu ${ }^{2}$ and Yongtao Xiao ${ }^{2,3^{*}}$
}

\begin{abstract}
Background: The poor understanding of pathogenesis in idiopathic pulmonary fibrosis (IPF) impaired development of effective therapeutic strategies. The aim of the current study is to investigate the roles of long non-coding RNA H19 (IncRNA H19) in the pulmonary inflammation and fibrosis of IPF.

Methods: Bleomycin was used to induce pulmonary inflammation and fibrosis in mice. The mRNAs and proteins expression in lung tissues was determined by quantitative real-time polymerase chain reaction (qRT-PCR) and western blot. H19 knockout $\left(\mathrm{H}_{19^{--}}\right)$mice were generated by CRISPR/Cas9.

Results: The expression of H19 mRNA was up-regulated in fibrotic lungs patients with IPF as well as in lungs tissues that obtained from bleomycin-treated mice. $\mathrm{H}^{19^{-/-}}$mice suppressed bleomycin-mediated pulmonary inflammation and inhibited the $116 /$ Stat3 signaling. H19 deficiency ameliorated bleomycin-induced pulmonary fibrosis and repressed the activation of TGF- $\beta / \mathrm{Smad}$ and S1 pr2/Sphk2 in the lungs of bleomycin-treated mice.
\end{abstract}

Conclusions: Our data suggests that $\mathrm{H} 19$ is a profibrotic InCRNA and a potential therapeutic target for IPF.

Keywords: Pulmonary fibrosis, IncRNA H19, Smad, S1 pr2

\section{Background}

Idiopathic pulmonary fibrosis (IPF) is a progressive and highly lethal pulmonary fibrotic lung disease with poor treatment and unknown etiology, which rises significantly with age and higher in men [1-4]. Patients with IPF present similar characteristics to the usual interstitial pneumonia (UIP), including extracellular matrix deposition, alveolar architectural disruption, and subpleural honeycombing [5]. The patients with IPF usually have clinical experiences from cough to respiratory insufficiency and have a median survival time of 3 to 5 years after diagnosis [1, 4]. Unfortunately, there are currently

\footnotetext{
*Correspondence: xiaoyongtao@xinhuamed.com.cn

${ }^{3}$ Department of Pediatric Surgery, Xin Hua Hospital, School of Medicine,

Shanghai Jiao Tong University, No. 1665, Kong Jiang Road, Shanghai, China

Full list of author information is available at the end of the article
}

no effective therapies capable of stabilizing or improving lung function for patients with IPF.

Long non-coding RNAs (lncRNAs) are defined as nonprotein encoding RNA molecules that are more than $200 \mathrm{bp}$ long in length [6]. IncRNAs have been shown to play important roles in different physiological activities, such as gene imprinting, cell proliferation, differentiation, apoptosis, migration, and immune responses [7, 8]. Recent studies have shown that aberrant expression of lncRNAs are associated with a number of human diseases, including cardiovascular, neurodegenerative, lung diseases, tumors and infections [9-15]. The lncRNA H19 is an imprinted and maternally expressed gene that plays a vital role in the controlling the cell proliferation and differentiation [16-18]. The others and our recent studies both indicate that hepatic $H 19$ level is correlated with the severity of cholestatic injury and liver fibrosis in mice [19, 20]. Furthermore, $H 19$ was also related to progression of original author(s) and the source, provide a link to the Creative Commons licence, and indicate if changes were made. The images or other third party material in this article are included in the article's Creative Commons licence, unless indicated otherwise in a credit line to the material. If material is not included in the article's Creative Commons licence and your intended use is not permitted by statutory regulation or exceeds the permitted use, you will need to obtain permission directly from the copyright holder. To view a copy of this licence, visit http://creativecommons.org/licenses/by/4.0/. The Creative Commons Public Domain Dedication waiver (http://creativeco mmons.org/publicdomain/zero/1.0/) applies to the data made available in this article, unless otherwise stated in a credit line to the data. 
lung cancer and lung fibrosis [21-24]. Although these studies suggest a causal link among H19 and pulmonary injury, it remains unknown whether and to what extent H19 is involved in the regulation of pulmonary fibrosis in vivo. In present study, we identified $H 19$ as an upregulated lncRNA in the lungs of pulmonary fibrosis. We further determined the functional roles and underlying mechanisms of $\mathrm{H} 19$ in pulmonary fibrosis, which suggested $H 19$ acts as a profibrotic lncRNA in the lungs.

\section{Materials and methods Materials}

Hydroxyproline Assay Kit (Cat. No. MAK008-1KT, Sigma-Aldrich, St. Louis, MO), PowerUp SYBR-Green Master Mix kit (Cat. No. A25742) and a High Capacity cDNA Reverse Transcription kit (Cat. No. 4368814) were obtained from Applied Biosystems (Foster City, CA). NuPAGE 10\% Bis-Tris gel (Cat. No. NP0301BOX, Invitrogen, Carlsbad, CA). Bleomycin (Cat. No. HY-17565, MedChemExpress, LLC, NJ), The antibodies used in this study were showed in Additional file 1: Table S1.

A mouse model of bleomycin-induced pulmonary fibrosis $H 19^{-/}$(H19 $\Delta$ Exon1-5) mice were generated by CRISPR/Cas9-mediated genome engineering in C57BL/6J mice as our previously described [20]. The animal procedures were approved by the Shanghai Jiao tong University School of Medicine affiliated Xin Hua hospital Animal Care and Use Committee (XHECF-2020-008). The mice (about 8 weeks old) were divided into four groups: wild type $(W t)$ sham $(\mathrm{n}=8-12), H 19^{-/-}$ sham $(\mathrm{n}=6-10)$, wild type $(W t)$ treated with bleomycin (BLM) $(\mathrm{n}=8-12)$ and $H 19^{-/-}$treated with bleomycin (BLM) $(n=8-12)$. For bleomycin administration, mice were anaesthetized with $2 \%$ isoflurane, and then instilled intratracheally with bleomycin ( $3.5 \mathrm{mg} / \mathrm{kg}$ body weight) in $100 \mu \mathrm{l} \mathrm{PBS}$, as previously described [25, 26]. After 4 weeks, the lung tissues were collected for RNA, protein, collagen content analyses and histological analysis. The degree of fibrosis was quantitated using an Ashcroft score in a blinded manner according to the described method [27].

\section{Fluorescence in situ hybridization (FISH)}

H19 FISH in mouse lung tissue was performed using a commercially available RNAscope Multiplex Fluorescent Reagent Kit v2 (Advanced Cell Diagnostics, Newark, CA) and RNAscope ${ }^{\circledR}$ Probe-Mm-H19 (\#423751, Advanced Cell Diagnostics, Newark, CA) according to the manufacturer's instruction. Fluorescent staining targeting Sftpc protein was performed followed H19 FISH.

\section{Quantitative real-time polymerase chain reaction (qRT-PCR)}

Total RNA was extracted from left lung of mice using the RNeasy kit (Qiagen, Hilden, Germany) according to the protocol of the manufacture and $2 \mu \mathrm{g}$ of total RNA was used to synthesize the 1 st cDNA using a High Capacity cDNA Reverse Transcription kit (Applied Biosystems, Foster City, CA). The real-time PCR reactions were performed on the ViiA 7 Real-Time PCR System (Applied Biosystems, Foster City, CA) using PowerUp SYBR-Green Master Mix kit (Applied Biosystems, Foster City, CA). All samples were assayed in triplicate, and data were normalized to endogenous control Hprt1. Relative RNA expression levels were calculated using the ${ }^{\Delta \Delta} \mathrm{Ct}$ method. The primers are listed in Additional file 1: Table S2.

\section{Western blotting}

A total $30 \mathrm{mg}$ left lung tissues was homogenized in $300 \mu$ l RIPA buffer (Invitrogen, Carlsbad, CA) supplemented with a protease inhibitor cocktail (Servicebio, Wuhan, China). After determining the protein concentration, the equal amounts of protein were separated on NuPAGE 10\% Bis-Tris gels (Invitrogen, Carlsbad, CA) and transferred onto polyvinylidene difluoride (PVDF) membranes. After blocking in 5\% nonfat milk at room temperature for $60 \mathrm{~min}$, membranes were incubated with the primary antibodies overnight at $4{ }^{\circ} \mathrm{C}$. The membranes were washed three times for $30 \mathrm{~min}$ with TBST (containing $0.1 \%$ Tween-20), and then incubated with secondary antibodies. After final washes with TBST, the signals were detected using ECL chemiluminescence reagent Kit (Pierce, Rockford, IL, USA). The primary antibodies performed in this study as showed in Additional file 1: Table S1.

\section{Histology and immunofluorescence (IF)}

The right lung tissues were immediately fixed in $10 \%$ neutral buffered formalin for $24 \mathrm{~h}$ and go through dehydration, clearing and paraffin embedding. Sections were mounted on positively charged slides after cutting at $4 \mu \mathrm{m}$ thick, baked at $65^{\circ} \mathrm{C}$ for $1 \mathrm{~h}$ and then stored at room temperature (RT) for later use. Fibrosis was performed using mason's trichrome (Genmed Scientifics, Wilmington, DE, USA) and Sirius red stain (Servicebio, Wuhan, China) following the protocols of manufactures. For immunofluorescence (IF) assay, the slides were incubated with xylol and descending concentrations of ethanol. Endogenous peroxidases were blocked by using $0.3 \%$ $\mathrm{H}_{2} \mathrm{O}_{2}$ for $10 \mathrm{~min}$ at RT. After antigen retrieval, blocking was performed using $5 \%$ bovine serum albumin for 
$30 \mathrm{~min}$ at RT. The antibodies used here were listed on Additional file 1: Table S1.

\section{Hydroxyproline assay}

The amount of collagen in the lung tissues was determined by a Hydroxyproline Assay Kit according to the manufacturer's protocol (Cat. No. MAK008-1KT, SigmaAldrich, St. Louis, MO). Briefly, about $10 \mathrm{mg}$ lung tissues were homogenized in $100 \mu \mathrm{l}$ water with $100 \mu \mathrm{l}$ concentrated hydrochloric acid $(\mathrm{HCl}, 12 \mathrm{M})$ and hydrolyzed at $120{ }^{\circ} \mathrm{C}$ for $3 \mathrm{~h}$. Transfer $20 \mu \mathrm{l}$ of supernatant at $60^{\circ} \mathrm{C}$ until completely desiccated. Chloramine T/Oxidation Buffer Mixture was added at room temperature for $5 \mathrm{~min}$, followed by the addition of Diluted DMAB Reagent and incubation at $60{ }^{\circ} \mathrm{C}$ for $90 \mathrm{~min}$. Measure the absorbance of samples and standards at $560 \mathrm{~nm}$, and hydroxyproline content was expressed as $\mu \mathrm{g}$ per mg lung tissue.

\section{Statistical analysis}

All data were expressed as mean \pm SD (standard deviation). For comparisons of different groups, statistical significance was determined by Student's t-test or ANOVA analysis. P-value less than 0.05 was considered statistically significant.

\section{Results}

\section{$H 19$ is up-regulated in fibrotic lungs}

Analysis of publicly available datasets showed that IncRNA H19 expression was more highly expressed in lung tissue from patients with IPF compared to normal lung tissue, but there was no significant difference between IPF patients and other interstitial lung diseases (ILD) (Fig. 1a) [28, 29]. Fibrotic genes, including ACTA2, COL1A2 and MMP7, increasingly expressed in lung tissue from patients with IPF compared to lung tissue from patients with other ILD and to normal lung tissue (Fig. 1a) [28, 29]. In addition to, H19 expression increased upon bleomycin-induced lung fibrosis in rats. H19 expression peaked after about 2 weeks of bleomycintreatment, and then $\mathrm{H} 19$ levels returned to an amount comparable to controls (Fig. 1b) [30]. In current study, Fluorescent in situ hybridization (FISH) assay showed that $H 19$ expression increased in lungs of bleomycintreated mice ( 2 weeks) and located at alveolar epithelium and capillaries (Fig. 1c). Furthermore, immunofluorescent staining of surfactant protein $\mathrm{C}$ (Sftpc), a marker for type 2 epithelial cells (AEC2s), indicated that H19 was also expressed and up-regulated in AEC2s following bleomycin-treatment (Fig. 1c). The qRT-PCR assay confirmed that $H 19$ increasingly expressed in the lungs of mice with bleomycin (BLM) treatment (Fig. 1d, e).

\section{H19 deficiency represses bleomycin-induced lung inflammatory response}

$H 19$ knock out $\left(\mathrm{H} \mathrm{9}^{-/-}\right)$mice here were used to elucidate the roles of $H 19$ in bleomycin-induced pulmonary inflammation and fibrosis. After 4-week BLM-treatment, immunofluorescence (IF) staining showed the $\mathrm{H}^{-9^{-/}}$ BLM mice had less $\mathrm{CD} 45^{+}$cells accumulated in the lungs than that in lungs of Wt BLM mice (Fig. 2a). RT-PCR analysis showed that $\mathrm{CD} 11 \mathrm{~b}$ and $\mathrm{Ccr} 2$ genes expression was reduced significantly in lungs of $H 19^{-/-}$mice when compared to that of $W t$ mice (Fig. 2b). The inflammatory markers, including F4/80, CD11b, Ccl20, $\mathrm{Il1b}$ and Ccr2 increased in $W t B L M$ mice compared to $W T$ sham mice, but decreased in $\mathrm{H}_{19^{-/}}$BLM mice (Fig. 2b). Western blot results indicated that protein expression levels of $\mathrm{Il}$ and p-Stat3 were decreased in lungs of $H 19^{-1-}$ BLM mice relative to the $W t$ BLM (Fig. 2c, d).

\section{H19 knockout ameliorates bleomycin-induced pulmonary fibrosis}

As shown in Fig. 3, histopathological analysis firstly showed reduced fibrosis in the $H 19^{-/-}$BLM mice (Fig. 3a, b). The haematoxylin-eosin (H\&E) staining and Collagen I immunofluorescence (IF) staining showed the fibrosis increased in $W t$ BLM mice compared to the $W t$ sham mice, but not in lungs of $H 19^{-/-}$BLM mice (Fig. 3a). The Masson's Trichrome staining and Sirius red staining further indicated that 4-week BLM significantly induced lung fibrosis in $W T$ mice, but had much less impact in $\mathrm{H}^{-9^{-/}}$mice (Fig. 3a). Consistently, quantitation of lung fibrosis in a blinded manner revealed the Ashcroft score decreased significantly in $H 19^{-/-}$BLM mice when compared to Wt BLM mice (Fig. 3b). Furthermore, the pulmonary hydroxyproline levels were significantly increased in Wt BLM mice, but not in $H 19^{-/}$BLM mice (Fig. 3c). At molecular level, $H 19^{-/-}$mice had decreased

(See figure on next page.)

Fig. 1 H19 increased in lungs of pulmonary fibrosis. a Data for H19 mRNA expression extracted from the GEO database, comparing whole extracts of lung tissue from human patients diagnosed with IPF $(n=50)$ and other interstitial lung diseases (ILD) $(n=35)$ and from control subjects ( $n=55$ ) (GSE47460). b Data for H19 mRNA expression extracted from the GEO microarray database, comparing whole extracts of lung tissue from bleomycin-induced lung fibrosis in rat ( $n=5$ animals per bleomycin-treated group and $n=22$ for saline controls). c Representative images of FISH targeting $\mathrm{H} 19$ (red) and immunofluorescence (IF) staining of Sftpc in lungs of Sham and bleomycin-treated mice. $\mathbf{d}$ The relative H19 mRNA levels in the lungs of Sham wild type $(\mathrm{Wt}, \mathrm{n}=8)$, Sham $\mathrm{H} 19$ knockout $\left(H 19^{-/-}, \mathrm{n}=6\right)$ Wt bleomycin $(\mathrm{BLM}, \mathrm{n}=8)$ and $\mathrm{H}_{19^{-/-}}$BLM $(\mathrm{n}=10)$ mice were determined by real-time RT-PCR. The Hprt1 was used as an internal control. e Representative images of the DNA agarose gels of H19 and Hprt1 


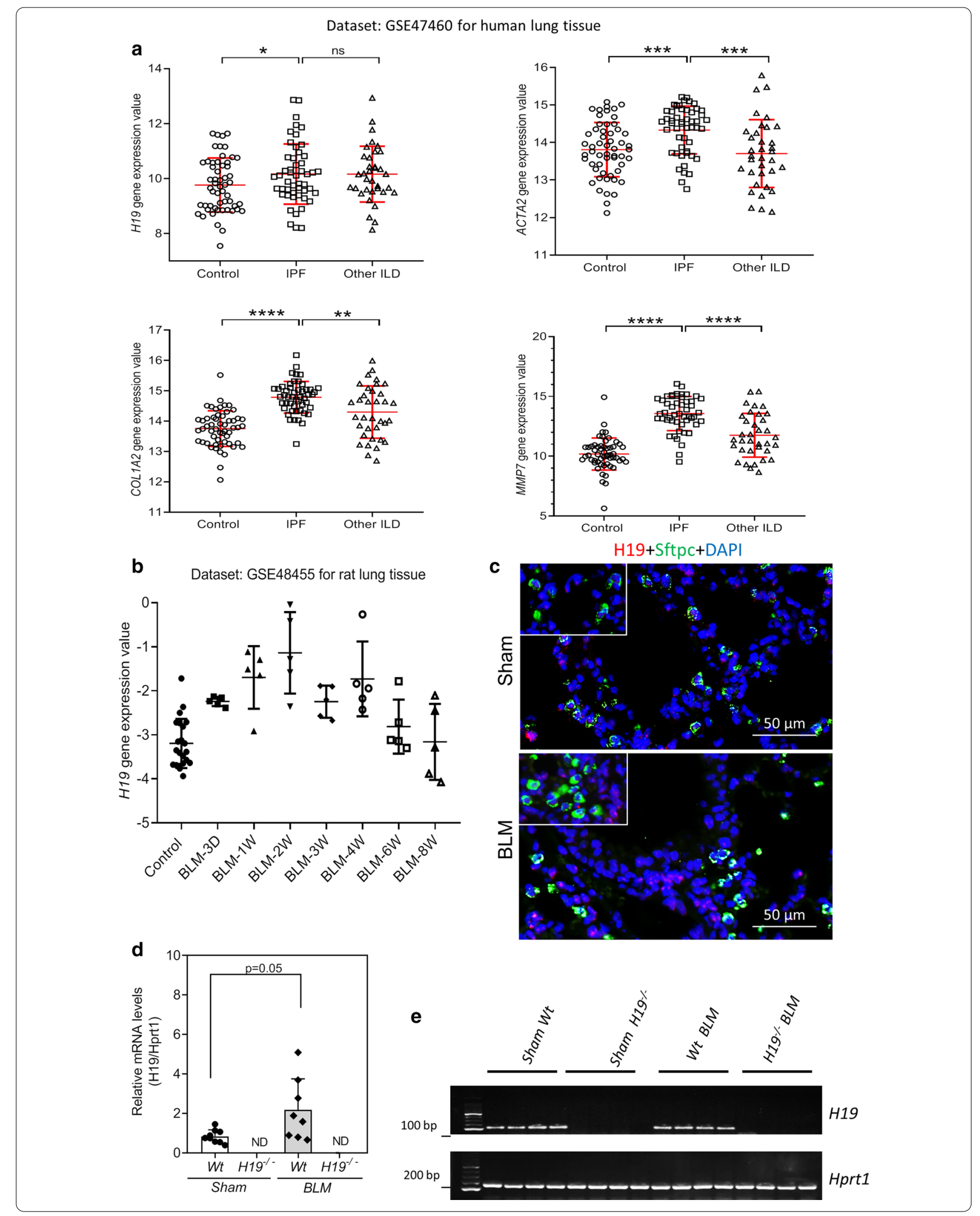


(See figure on next page.)

Fig. 2 H19 knockout inhibited bleomycin-induced pulmonary inflammation in mice. a Representative immunofluorescence (IF) images of CD45

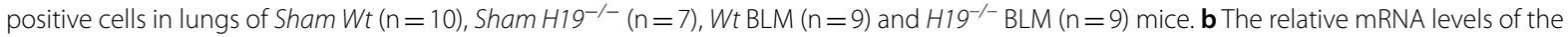
inflammatory marker genes including F4/80,CD11b, CCI2O, IL1b and Yml, in the lungs of Sham Wt $(n=10)$, Sham H19-/- $(n=7), W t B L M(n=9)$ and $H 19^{-/-}$BLM $(n=9)$ mice. The Hprt1 was used as an internal control. c Representative images of the immune blots of II6, p-Stat3, Stat3 and $\beta$-Actin. d Relative protein expression levels of 116 and $p$-Stat3 were normalized using $\beta$-actin or Stat3. Statistical significance: ${ }^{*} p<0.05$; ${ }^{*} p<0.01$; $n s$ not significant

expression of $T g f b 1$ and Acta 2 mRNA in the lungs in relation to $W t$ animals (Fig. 3d). The mRNA levels of Tgfb1, Acta2 and Col1a1 (Fig. 3d) and protein expression of Colla1 (Fig. 3e, f) reduced in $H 19^{-/-}$BLM mice compared to the $W t$ BLM mice.

\section{$H 19$ depletion attenuated the pathways of TGF- $\beta / \mathrm{Smad}$ and S1 pr1/Sphk2 in fibrotic lungs}

TGF- $\beta /$ Smad signaling is the key regulating pathway in fibrogenesis [31]. In this study, we showed that the TGF- $\beta$ mRNA level and protein levels of p-Smad2 and p-Smad3 were increased in the Wt BLM mice, compared with $W t$ sham mice, while these proteins reduced in $H 19^{-/-}$BLM mice (Fig. 4a, b). Our previous study had reported that S1pr2 and SphK2 played an important role in promoting liver fibrosis [20]. As shown in Fig. 4, Western blot results indicated that protein expression levels of S1pr2 and SphK2 were increased in lungs of Wt BLM mice compared to Wt sham mice, but decreased in lungs of $H 19^{-/-}$ BLM (Fig. 4c, d).

\section{$H 19$ deficiency decreased AEC2s proliferation in lungs of bleomycin-treated mice}

In the lung sections from the $H 19^{-1-}$ BLM mice, immunofluorescence results showed that expression of Sftpc was decreased relative to that of the Wt BLM mice (Fig. 5a). Additionally, the number of Ki67-positive cells was also reduced in the $H 19^{-/-}$BLM mice compared to the Wt BLM mice (Fig. 5a and Additional file 1: Figure S1). Consistently, western blot results indicated that protein expression levels of Sftpc reduced in the $\mathrm{H} \mathrm{9}^{-/-}$ BLM mice compared to the Wt BLM mice (Fig. 5b, c). In addition to, the proteins of p-Egfr decreased in lungs of $H 19^{-/-}$BLM mice compared to the Wt BLM mice (Fig. 5b, c).

\section{Discussion}

Presently, the poor understanding in the pathogenesis of IPF has resulted in a lack of effective therapies. In the current study, we showed that the lncRNA H19 was upregulated in the fibrotic lungs of IPF patients and bleomycin-treated mice. Functionally, H19 deficiency reduced pulmonary inflammation and inhibiting Il6/Stat3 signaling. H19 knockout ameliorated bleomycin-induced pulmonary fibrosis through attenuating the TGF- $\beta / \mathrm{Smad}$ and S1pr2/Sphk2 pathways. Moreover, we also indicated that $H 19$ expressed in the type 2 epithelial cells (AEC2s) and contributed to the proliferation of AEC2s.

H19 is an imprinted and maternally expressed transcript, which is one of the few well-characterized lncRNA [32, 33]. Aberrant expression of $H 19$ has been related to a variety of human diseases [34-38]. Using a public datasets, it showed that IPF patients had higher levels of H19 mRNA in lungs when compared to the control subjects. Similarly, H19 mRNA also increased in a model of bleomycin-induced pulmonary fibrosis. In current study, we also showed that $H 19$ expression increased in lungs of bleomycin-treated mice and located at alveolar epithelium and capillaries. From the above findings, we hypothesize that $H 19$ may play an important role in the pathogenesis of IPF. To realize our aim of this study, we firstly generated a $\mathrm{H} 19$ deficiency mouse $\left(\mathrm{H}_{19^{-/-}}\right)$.

Pulmonary inflammation and fibrosis caused by repetitive lung injury underlies the IPF. In vivo studies, we showed that $H 19^{-/-}$mice could attenuate bleomycin-induced pulmonary inflammation. During the bleomycin-induced mice, the CD11b and Ccr2 mRNA expression increased the lung of wild type mice, but not in that of $H 19^{-/-}$mice. Recently, Li et al., reported that $H 19$ significantly induced the expression and secretion of chemokine ( $\mathrm{C}-\mathrm{C}$ motif) ligand 2 (CCL-2) that could accumulate the monocytes from circulation into livers [39]. It thus suggests that $H 19$ contributes to the pulmonary inflammation may via attracting the CD11b monocytes into the lung after injures. The signaling studies presented here revealed that Il6/Stat 3 was reduced in the bleomycin damaged lungs of $\mathrm{H}^{-1-}$ mice. In the injured lung, STAT3 rapidly activated and increased the production of the proinflammatory molecules IL1 $\beta, I L 6, T N F-\alpha, i N O S$ and CCL2 [40-43]. It thus propose that $H 19^{-/-}$mice reduced bleomycininduced pulmonary inflammation may through attenuating the Il6/Stat3 signaling. In vivo studies further revealed $H 19$ deficiency significantly reduced bleomycin-induced pulmonary fibrosis. TGF- $\beta /$ smad signaling is one of the key pathways responsible for pulmonary fibrosis [31, 44-46]. The current study indicated that $H 19^{-1-}$ mice attenuated the TGF- $\beta /$ smad signaling in bleomycin damaged lungs by reducing the expression of $T g f b 1$ mRNA and activated the Smad2/3 protein. 
a
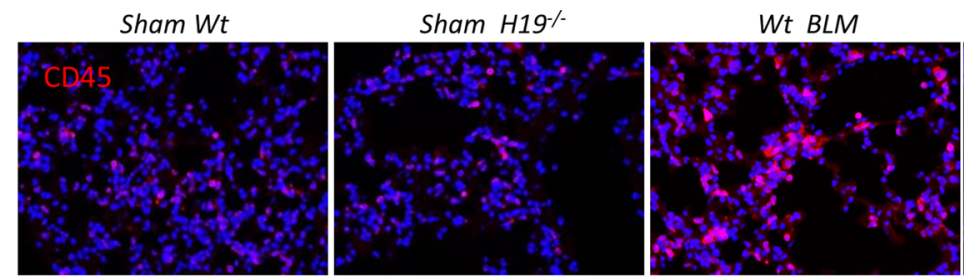

$H 19 \% B L M$

b
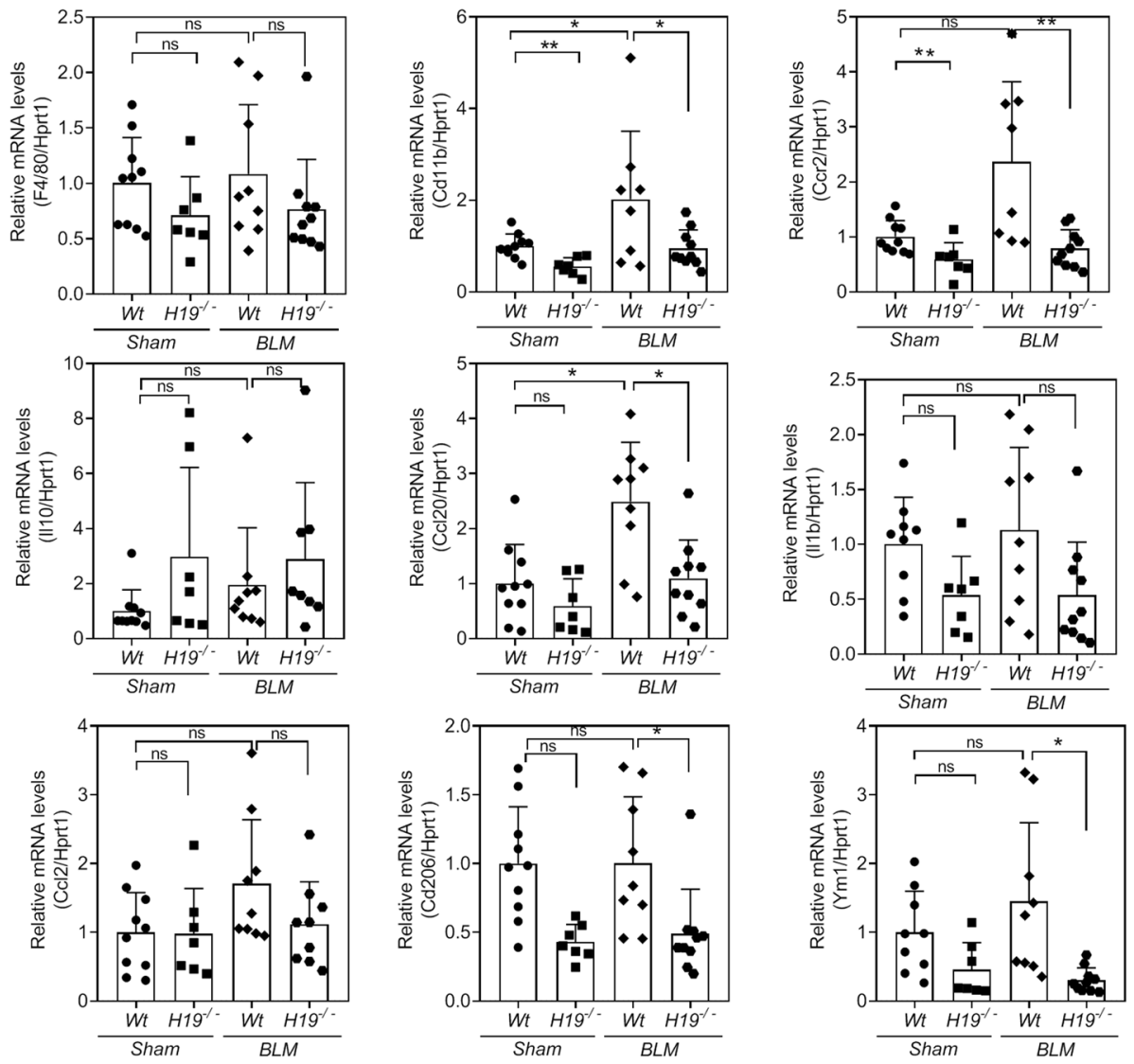

C

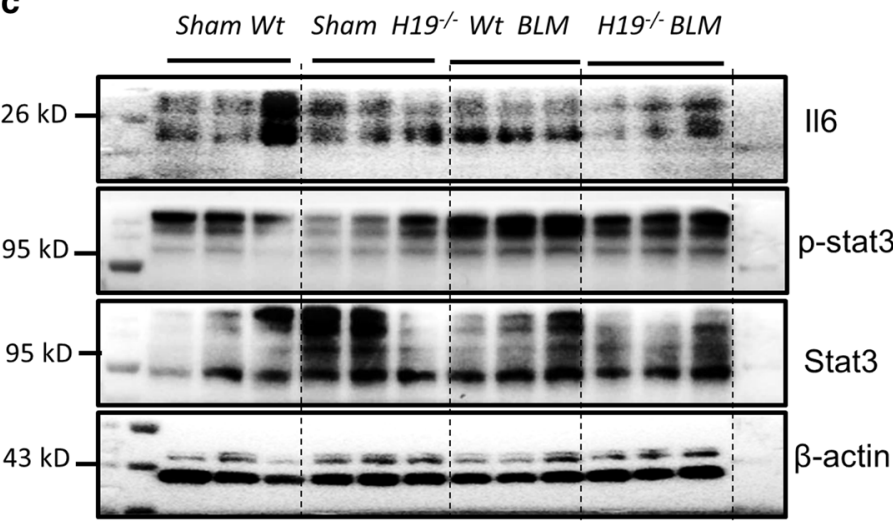

d

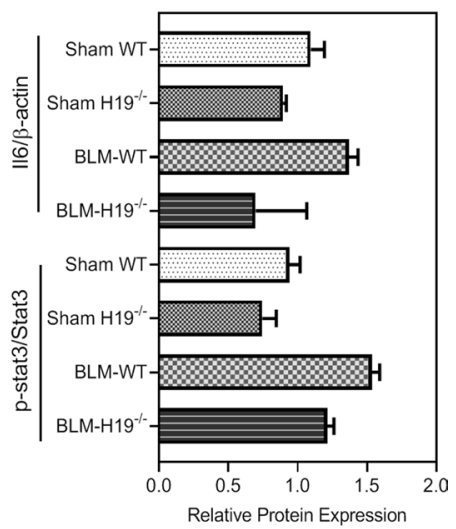



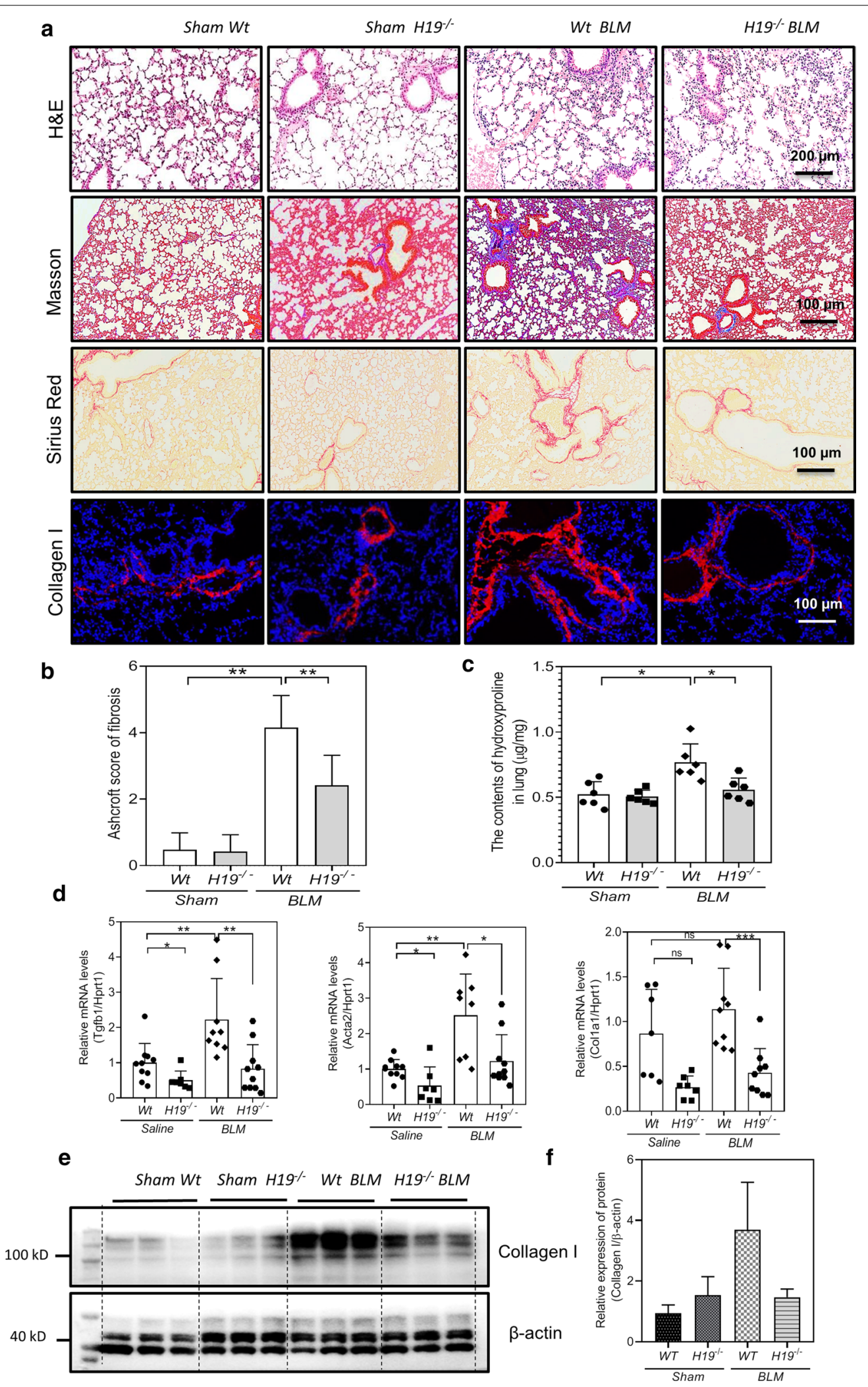
(See figure on previous page.)

Fig. 3 H19 deficiency ameliorated bleomycin-induced pulmonary fibrosis in mice. a Representative images of hematoxylin-eosin (H\&E) staining,

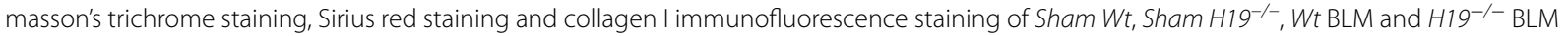

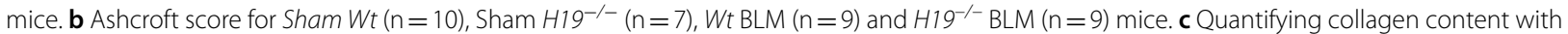
hydroxyproline assay in the lungs of Sham Wt, Sham H19-/- Wt BLM and H19-/- BLM mice. Each group, $\mathrm{n}=6-8$. d Real-time PCR analysis for Tgfb 1, Colla1 and Acta2 in the lungs of Sham Wt, Sham H19-/- Wt BLM and $\mathrm{H}_{19}^{-/-}$BLM mice. Each group, $\mathrm{n}=8-10$. e Western blot analysis for collagen type I the lungs of Sham Wt, Sham H19 ${ }^{-/-}$, Wt BLM and $\mathrm{H} 9^{-/-}$BLM mice. $\mathbf{f}$ Quantification of the panel (e)

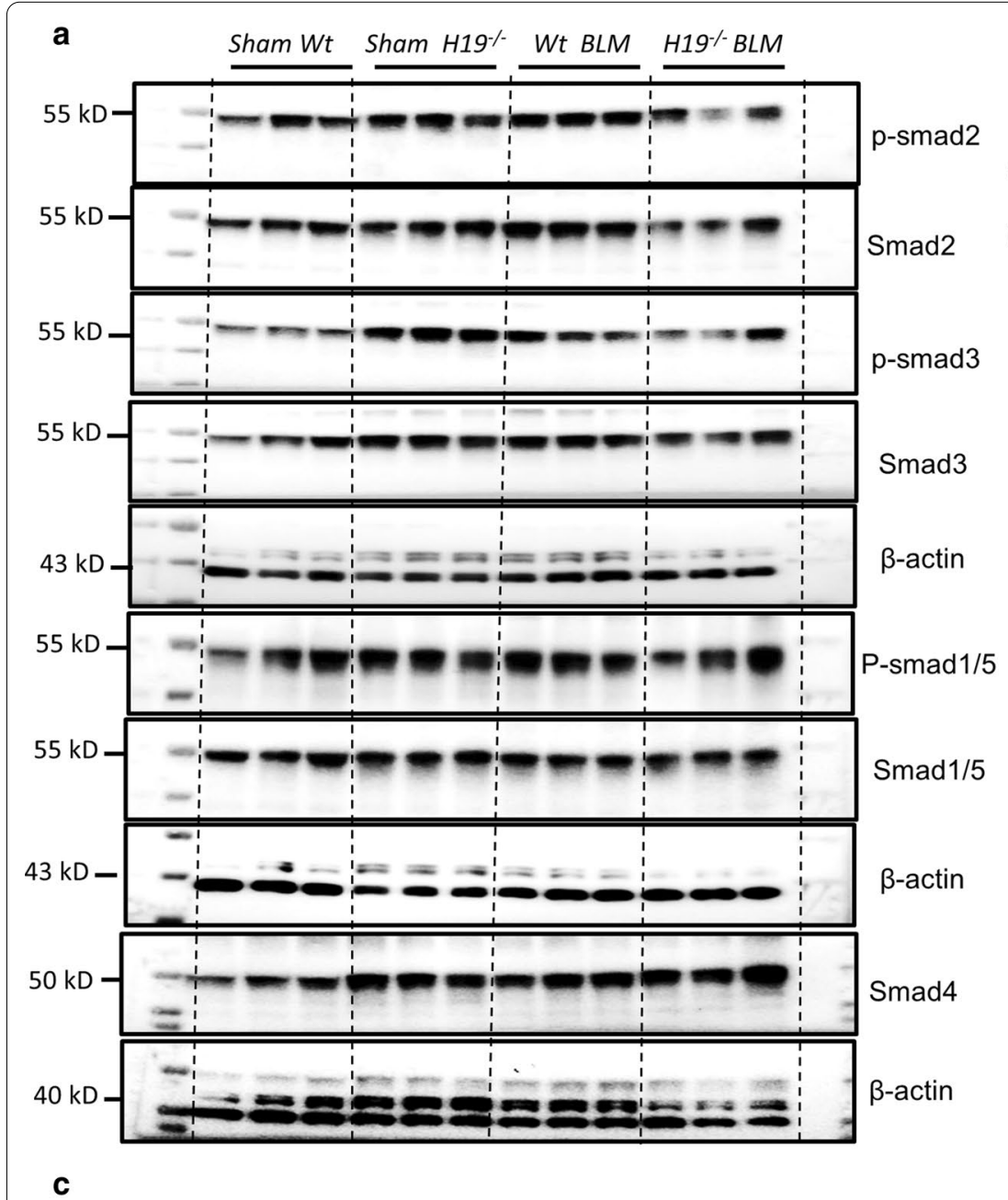

\section{b}
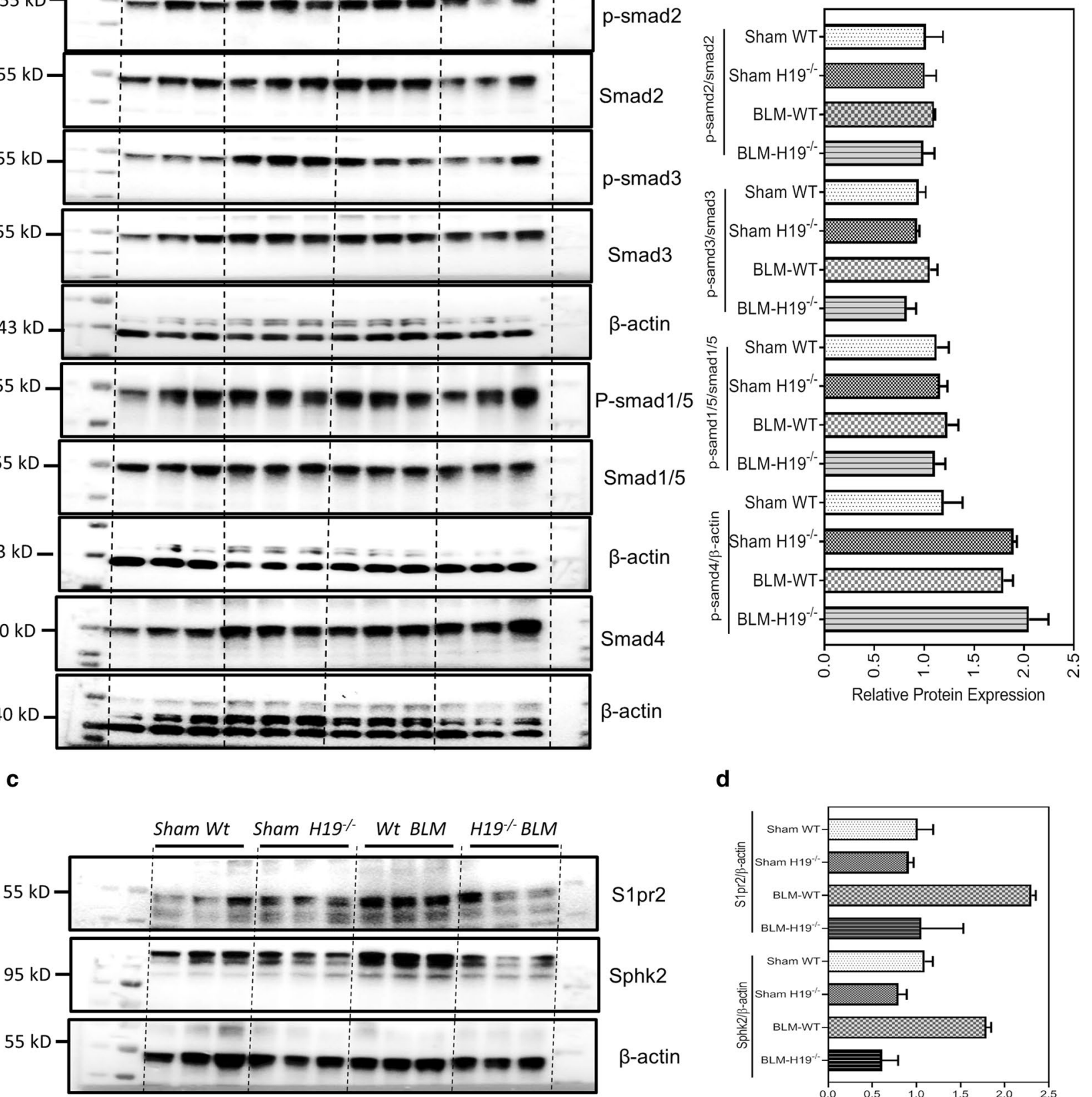

d

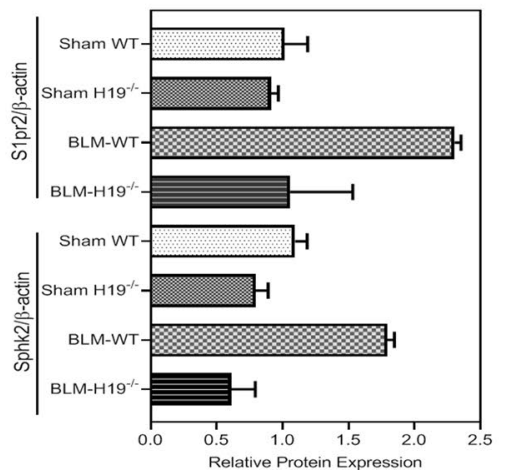

Fig. $4 \mathrm{H} 19$ depletion altered the TGF- $/$ /Smads and S1 pr2/Sphk2 pathways in lungs of bleomycin-induced mice. a Western blot analysis for Smad1/5, Smad2, Smad3, Samd4 and their phosphorylated forms the lungs of Sham Wt, Sham H19-/, Wt BLM and $\mathrm{H}_{19^{-/}}$BLM mice. b Quantification of the panel (a). c Western blot analysis for S1 pr2 and Sphk2 in the lungs of Sham Wt, Sham H19 ${ }^{-/-}$, Wt BLM and $\mathrm{H}_{1} 9^{-/-}$BLM mice. d Quantification of the panel (c) 

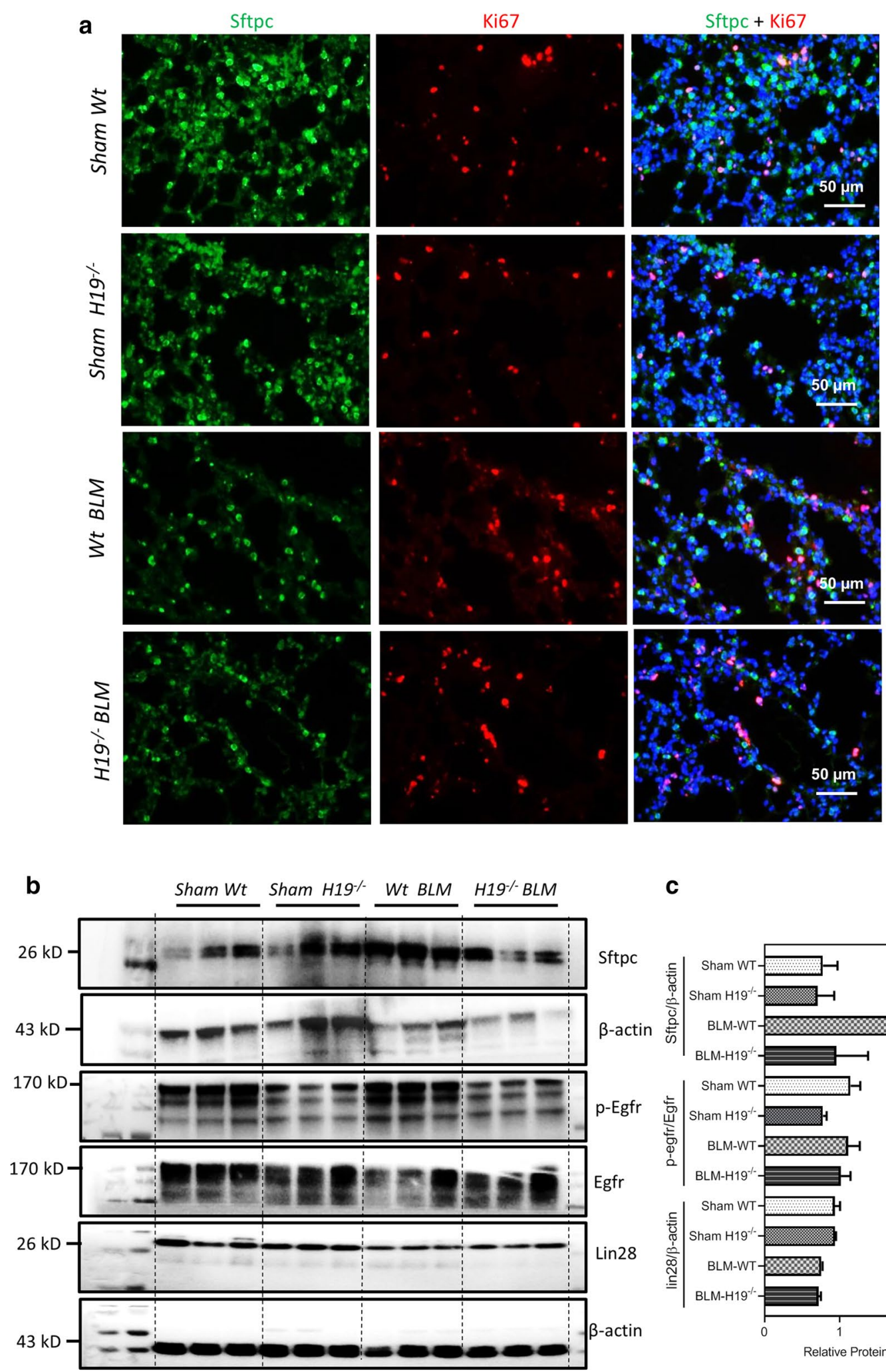

C

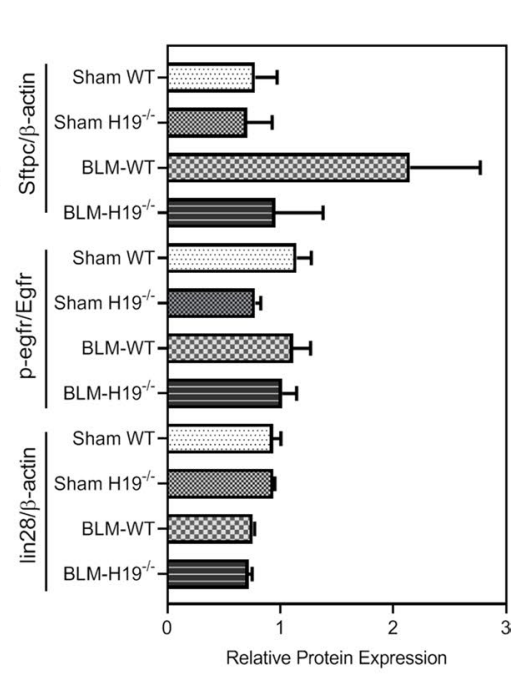

Fig. 5 H19 depletion reduced cell proliferation in lungs of bleomycin-induced mice. a Representative images of co-staining for Sftpc and Ki67 in the lungs of Sham Wt, Sham H19--- Wt BLM and $\mathrm{H}^{-19^{--}}$BLM mice. $\mathbf{b}$ Western blot analysis for Sftpc, p-Egfr, Egfr, Lin28 and $\beta$-actin in the lungs of

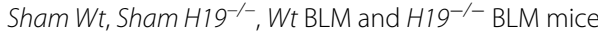


Consistently, in vitro study revealed that $H 19$ can target miR-140 and regulate the TGF- $\beta / \operatorname{Smad} 3$ pathway [24]. Moreover, $H 19$ could enhance TGF- $\beta$ signaling in both hepatic stellate cells and hepatocytes and facilitate liver fibrosis [47]. $H 19$ has been reported to accelerate TGF$\beta 1$-induced tenogenic differentiation in vitro and promoted tendon healing in a mouse tendon defect model [48]. Sphingosine-1-phosphate and its receptor S1pr2 have been shown to promote lung fibrosis [49-53]. Our previous study also showed that $H 19$ could activate the S1pr2/SphK2 signalling pathway in the cholestatic livers. The current study indicated that S1pr2/SphK2 signalling was activated in the bleomycin-treated lungs, but these effects were attenuated by $H 19$ knockout. We thus propose that $H 19$ contribute to lung fibrosis of IPF may via regulating both TGF- $\beta /$ smad and S1pr2/SphK2 signalling. Epidermal growth factor receptor (EGFR) is a major driver of lung adenocarcinoma, which is essential to lung cancer cell proliferation [54]. The present study also showed $H 19$ deficiency repressed EGFR activating and suppressed the ACE2s proliferation.

\section{Conclusion}

In summary, we demonstrated that the H19 is a potential therapeutic target for IPF patients. We propose two novel mechanisms underlying $H 19$ activity in the pathogenesis of IPF. H19 knockout inhibits pulmonary inflammation by attenuating the Il6/Stat3 signaling. $H 19$ acts as a profibrotic lncRNA in the lung of IPF via regulating the TGF $\beta /$ Smad and S1pr2/Sphk2.

\section{Supplementary information}

Supplementary information accompanies this paper at https://doi. org/10.1186/s12931-020-01534-6.

Additional file 1: Table S1. Antibody information. Table S2. Sequences of primers. Figure S1. Quantification of the Fig. 5a.

\section{Abbreviations}

IPF: Idiopathic pulmonary fibrosis; IncRNA: Long non-coding RNA H19; UIP: Usual interstitial pneumonia; RT-PCR: Real-time polymerase chain reaction; IF: Immunofluorescence; H\&E: Hematoxylin-eosin; EGFR: Epidermal growth factor; TGF- $\beta$ receptor: Transforming growth factor- $\beta$; S1PR2: Sphingosine1-phosphate receptor 2; SphK2: Sphingosine kinase 2; ACTA2: Alpha 2 smooth muscle actin; COL1A2: Collagen type I alpha 2; MMP7: Matrix metalloproteinase 7 .

\section{Acknowledgements}

The authors extend their gratitude to Shanshan Chen and Yang Liu for their technical support and assistance in performing the experiments.

\section{Authors' contributions}

$X W$ and $Y X$ developed study concept and design, acquisition of data, analysis and interpretation of data. XW, XT, JD and YL performed and analyzed most of the experiments. $X W$ and $Y X$ wrote the manuscript. All authors read and approved the final manuscript.

\section{Funding}

This study was supported by the National Natural Science Foundation of China (81770517).

Availability of data and materials

Original data can be requested from corresponding author.

\section{Ethics approval and consent to participate}

The animal experiments were approved by the Shanghai Jiao tong University School of Medicine affiliated Xin Hua hospital Animal Care and Use Committee(XHEC-F-2020-008)

\section{Consent for publication}

Not applicable.

\section{Competing interests}

The authors declare no competing financial interest.

\section{Author details}

${ }^{1}$ Department of Respiratory Medicine, Shanghai Pulmonary Hospital, Tongji University School of Medicine, Shanghai, China. ${ }^{2}$ Shanghai Institute for Pediatric Research, Shanghai, China. ${ }^{3}$ Department of Pediatric Surgery, Xin Hua Hospital, School of Medicine, Shanghai Jiao Tong University, No. 1665, Kong Jiang Road, Shanghai, China.

Received: 14 July 2020 Accepted: 5 October 2020

Published online: 02 November 2020

References

1. King TE Jr, Pardo A, Selman M. Idiopathic pulmonary fibrosis. Lancet. 2011;378:1949-61.

2. Nalysnyk L, Cid-Ruzafa J, Rotella P, Esser D. Incidence and prevalence of idiopathic pulmonary fibrosis: review of the literature. Eur Respir Rev. 2012;21:355-61.

3. Fernandez Perez ER, Daniels CE, Schroeder DR, St Sauver J, Hartman TE, Bartholmai BJ, Yi ES, Ryu JH. Incidence, prevalence, and clinical course of idiopathic pulmonary fibrosis: a population-based study. Chest. 2010;137:129-37.

4. Raghu G, Weycker D, Edelsberg J, Bradford WZ, Oster G. Incidence and prevalence of idiopathic pulmonary fibrosis. Am J Respir Crit Care Med. 2006;174:810-6.

5. Travis WD, Costabel U, Hansell DM, King TE Jr, Lynch DA, Nicholson AG, Ryerson CJ, Ryu JH, Selman M, Wells AU, et al. An official American Thoracic Society/European Respiratory Society statement: update of the international multidisciplinary classification of the idiopathic interstitial pneumonias. Am J Respir Crit Care Med. 2013;188:733-48.

6. Ulitsky I, Bartel DP. lincRNAs: genomics, evolution, and mechanisms. Cell. 2013;154:26-46.

7. Fatica A, Bozzoni I. Long non-coding RNAs: new players in cell differentiation and development. Nat Rev Genet. 2014;15:7-21.

8. Monnier P, Martinet C, Pontis J, Stancheva I, Ait-Si-Ali S, Dandolo L. H19 IncRNA controls gene expression of the Imprinted Gene Network by recruiting MBD1. Proc Natl Acad Sci USA. 2013:110:20693-8.

9. Ponting CP, Oliver PL, Reik W. Evolution and functions of long noncoding RNAs. Cell. 2009;136:629-41.

10. Saha P, Verma S, Pathak RU, Mishra RK. Long noncoding RNAs in mammalian development and diseases. Adv Exp Med Biol. 2017; 1008:155-98

11. Wu GC, Pan HF, Leng RX, Wang DG, Li XP, Li XM, Ye DQ. Emerging role of long noncoding RNAs in autoimmune diseases. Autoimmun Rev. 2015;14:798-805.

12. Uchida S, Dimmeler S. Long noncoding RNAs in cardiovascular diseases. Circ Res. 2015;116:737-50.

13. Pastori C, Wahlestedt C. Involvement of long noncoding RNAs in diseases affecting the central nervous system. RNA Biol. 2012;9:860-70.

14. Li X, Wu Z, Fu X, Han W. Long noncoding RNAs: insights from biological features and functions to diseases. Med Res Rev. 2013;33:517-53.

15. Zhang J, Zhu Y, Wang R. Long noncoding RNAs in respiratory diseases. Histol Histopathol. 2018;33:747-56. 
16. Gomez JA, Wapinski OL, Yang YW, Bureau JF, Gopinath S, Monack DM, Chang HY, Brahic M, Kirkegaard K. The NeST long ncRNA controls microbial susceptibility and epigenetic activation of the interferongamma locus. Cell. 2013;152:743-54.

17. Liang WC, Fu WM, Wang YB, Sun YX, Xu LL, Wong CW, Chan KM, Li G, Waye MM, Zhang JF. H19 activates Wnt signaling and promotes osteoblast differentiation by functioning as a competing endogenous RNA. Sci Rep. 2016;6:20121.

18. Giovarelli M, Bucci G, Ramos A, Bordo D, Wilusz CJ, Chen CY, Puppo M, Briata P, Gherzi R. H19 long noncoding RNA controls the mRNA decay promoting function of KSRP. Proc Natl Acad Sci USA. 2014;111:E5023-5028.

19. Li X, Liu R, Yang J, Sun L, Zhang L, Jiang Z, Puri P, Gurley EC, Lai G, Tang $Y$, et al. The role of long noncoding RNA H19 in gender disparity of cholestatic liver injury in multidrug resistance 2 gene knockout mice. Hepatology. 2017;66:869-84.

20. Xiao Y, Liu R, Li X, Gurley EC, Hylemon PB, Lu Y, Zhou H, Cai W. Long noncoding RNA H19 contributes to cholangiocyte proliferation and cholestatic liver fibrosis in biliary atresia. Hepatology. 2019;70:1658-73.

21. Zhao Y, Feng C, Li Y, Ma Y, Cai R. LncRNA H1 9 promotes lung cancer proliferation and metastasis by inhibiting miR-200a function. Mol Cell Biochem. 2019;460:1-8.

22. Huang Z, Lei W, Hu HB, Zhang H, Zhu Y. H19 promotes non-small-cell lung cancer (NSCLC) development through STAT3 signaling via sponging miR-17. J Cell Physiol. 2018;233:6768-76.

23. Lu Q, Guo Z, Xie W, Jin W, Zhu D, Chen S, Ren T. The IncRNA H19 mediates pulmonary fibrosis by regulating the miR-196a/COL1A1 axis. Inflammation. 2018;41:896-903.

24. Wang X, Cheng Z, Dai L, Jiang T, Jia L, Jing X, An L, Wang H, Liu M. Knockdown of long noncoding RNA H19 represses the progress of pulmonary fibrosis through the transforming growth factor beta/Smad3 pathway by regulating MicroRNA 140. Mol Cell Biol. 2019;39:e00143-19.

25. Hecker L, Vittal R, Jones T, Jagirdar R, Luckhardt TR, Horowitz JC, Pennathur S, Martinez FJ, Thannickal VJ. NADPH oxidase-4 mediates myofibroblast activation and fibrogenic responses to lung injury. Nat Med. 2009;15:1077-81.

26. Koyama K, Goto H, Morizumi S, Kagawa K, Nishimura H, Sato S, Kawano H, Toyoda Y, Ogawa H, Homma S, Nishioka Y. The tyrosine kinase inhibitor TAS-115 attenuates bleomycin-induced lung fibrosis in mice. Am J Respir Cell Mol Biol. 2019;60:478-87.

27. Ashcroft T, Simpson JM, Timbrell V. Simple method of estimating severity of pulmonary fibrosis on a numerical scale. J Clin Pathol. 1988;41:467-70.

28. Peng X, Moore M, Mathur A, Zhou Y, Sun H, Gan Y, Herazo-Maya JD, Kaminski N, Hu X, Pan H, et al. Plexin C1 deficiency permits synaptotagmin 7-mediated macrophage migration and enhances mammalian lung fibrosis. FASEB J. 2016;30:4056-70.

29. Yu G, Tzouvelekis A, Wang R, Herazo-Maya JD, Ibarra GH, Srivastava A, de Castro JPW, Deluliis G, Ahangari F, Woolard T, et al. Thyroid hormone inhibits lung fibrosis in mice by improving epithelial mitochondrial function. Nat Med. 2018:24:39-49.

30. Bauer Y, Tedrow J, de Bernard S, Birker-Robaczewska M, Gibson KF, Guardela BJ, Hess P, Klenk A, Lindell KO, Poirey S, et al. A novel genomic signature with translational significance for human idiopathic pulmonary fibrosis. Am J Respir Cell Mol Biol. 2015:52:217-31.

31. Derynck R, Zhang YE. Smad-dependent and Smad-independent pathways in TGF-beta family signalling. Nature. 2003;425:577-84.

32. Khosla S, Aitchison A, Gregory R, Allen ND, Feil R. Parental allele-specific chromatin configuration in a boundary-imprinting-control element upstream of the mouse H19 gene. Mol Cell Biol. 1999;19:2556-66.

33. Bartolomei MS, Zemel S, Tilghman SM. Parental imprinting of the mouse H19 gene. Nature. 1991;351:153-5.

34. Stuhlmuller B, Kunisch E, Franz J, Martinez-Gamboa L, Hernandez MM, Pruss A, Ulbrich N, Erdmann VA, Burmester GR, Kinne RW. Detection of oncofetal h19 RNA in rheumatoid arthritis synovial tissue. Am J Pathol. 2003;163:901-11.

35. lempridee T. Long non-coding RNA H19 enhances cell proliferation and anchorage-independent growth of cervical cancer cell lines. Exp Biol Med. 2017;242:184-93.

36. Geng H, Bu HF, Liu F, Wu L, Pfeifer K, Chou PM, Wang X, Sun J, Lu L, Pandey $A$, et al. In inflamed intestinal tissues and epithelial cells, interleukin
22 signaling increases expression of $\mathrm{H} 19$ long noncoding RNA, which promotes mucosal regeneration. Gastroenterology. 2018;155:144-55.

37. Yoruker EE, Keskin M, Kulle CB, Holdenrieder S, Gezer U. Diagnostic and prognostic value of circulating IncRNA H19 in gastric cancer. Biomed Rep. 2018:9:181-6.

38. Zhang K, Luo Z, Zhang Y, Zhang L, Wu L, Liu L, Yang J, Song X, Liu J. Circulating IncRNA H19 in plasma as a novel biomarker for breast cancer. Cancer Biomark. 2016;17:187-94.

39. Li X, Liu R, Wang Y, Zhu W, Zhao D, Wang $X$, Yang H, Gurley EC, Chen W, Hylemon PB, Zhou H. Cholangiocyte-derived exosomal IncRNA H19 promotes macrophage activation and hepatic inflammation under cholestatic conditions. Cells. 2020;9:190.

40. Goodman RB, Pugin J, Lee JS, Matthay MA. Cytokine-mediated inflammation in acute lung injury. Cytokine Growth Factor Rev. 2003;14:523-35.

41. Severgnini M, Takahashi S, Rozo LM, Homer RJ, Kuhn C, Jhung JW, Perides G, Steer M, Hassoun PM, Fanburg BL, et al. Activation of the STAT pathway in acute lung injury. Am J Physiol Lung Cell Mol Physiol. 2004;286:L1282-1292.

42. Song Z, Zhao X, Gao Y, Liu M, Hou M, Jin H, Cui Y. Recombinant human brain natriuretic peptide ameliorates trauma-induced acute lung injury via inhibiting JAK/STAT signaling pathway in rats. J Trauma Acute Care Surg. 2015;78:980-7.

43. Zhao J, Yu H, Liu Y, Gibson SA, Yan Z, Xu X, Gaggar A, Li PK, Li C, Wei S, et al. Protective effect of suppressing STAT3 activity in LPS-induced acute lung injury. Am J Physiol Lung Cell Mol Physiol. 2016;311:L868-80.

44. Yao H, Wei S, Xiang Y, Wu Z, Liu W, Wang B, Li X, Xu H, Zhao J, Gao Y. Kangfuxin oral liquid attenuates bleomycin-induced pulmonary fibrosis via the TGF-beta1/Smad pathway. Evid Based Complement Alternat Med. 2019:2019:5124026.

45. Shen ZJ, Braun RK, Hu J, Xie Q, Chu H, Love RB, Stodola LA, Rosenthal LA, Szakaly RJ, Sorkness RL, Malter JS. Pin1 protein regulates Smad protein signaling and pulmonary fibrosis. J Biol Chem. 2012;287:23294-305.

46. Higashiyama H, Yoshimoto D, Okamoto Y, Kikkawa H, Asano S, Kinoshita M. Receptor-activated Smad localisation in bleomycin-induced pulmonary fibrosis. J Clin Pathol. 2007;60:283-9.

47. Zhu J, Luo Z, Pan Y, Zheng W, Li W, Zhang Z, Xiong P, Xu D, Du M, Wang B, et al. H19/miR-148a/USP4 axis facilitates liver fibrosis by enhancing TGF-beta signaling in both hepatic stellate cells and hepatocytes. J Cell Physiol. 2019;234:9698-710.

48. Lu YF, Liu Y, Fu WM, Xu J, Wang B, Sun YX, Wu TY, Xu LL, Chan KM, Zhang JF, Li G. Long noncoding RNA H19 accelerates tenogenic differentiation and promotes tendon healing through targeting miR-29b-3p and activating TGF-beta1 signaling. FASEB J. 2017;31:954-64.

49. Huang LS, Sudhadevi T, Fu P, Punathil-Kannan PK, Ebenezer DL, Ramchandran R, Putherickal V, Cheresh P, Zhou G, Ha AW, et al. Sphingosine kinase 1/S1P signaling contributes to pulmonary fibrosis by activating Hippo/YAP pathway and mitochondrial reactive oxygen species in lung fibroblasts. Int J Mol Sci. 2020;21:2064.

50. Park SJ, Im DS. Deficiency of sphingosine-1-phosphate receptor 2 (S1P2) attenuates bleomycin-induced pulmonary fibrosis. Biomol Ther. 2019;27:318-26.

51. Zhao J, Okamoto Y, Asano Y, Ishimaru K, Aki S, Yoshioka K, Takuwa N, Wada T, Inagaki Y, Takahashi C, et al. Sphingosine-1-phosphate receptor-2 facilitates pulmonary fibrosis through potentiating IL-13 pathway in macrophages. PLOS ONE. 2018;13:e0197604.

52. Huang LS, Berdyshev EV, Tran JT, Xie L, Chen J, Ebenezer DL, Mathew B, Gorshkova I, Zhang W, Reddy SP, et al. Sphingosine-1-phosphate lyase is an endogenous suppressor of pulmonary fibrosis: role of S1P signalling and autophagy. Thorax. 2015;70:1138-48.

53. Milara J, Navarro R, Juan G, Peiro T, Serrano A, Ramon M, Morcillo E, Cortijo J. Sphingosine-1-phosphate is increased in patients with idiopathic pulmonary fibrosis and mediates epithelial to mesenchymal transition. Thorax. 2012;67:147-56.

54. Stella GM, Luisetti M, Inghilleri S, Cemmi F, Scabini R, Zorzetto M, Pozzi E. Targeting EGFR in non-small-cell lung cancer: lessons, experiences, strategies. Respir Med. 2012;106:173-83.

\section{Publisher's Note}

Springer Nature remains neutral with regard to jurisdictional claims in published maps and institutional affiliations. 